\title{
Reproductive health services utilization and its associated factors among secondary school youths in Woreta town, South Gondar, North West Ethiopia: a cross sectional study
}

\author{
Addisu Taye Abate ${ }^{1 *}$, Aynalem Adu Ayisa ${ }^{2}$ and Tesfamichael G/Mariam W/Mariam²
}

\begin{abstract}
Objective: The aim of this study was to assess reproductive health service utilization and its associated factors among secondary school students in Woreta town, South Gondar, North east Ethiopia 2018.

Result: Out of the total 376 selected students, 345 were participated in the study with a response rate of $94 \%$. Of these respondents, 85 (24.6\%) of them utilized at least one reproductive health services in the past 1 year. Voluntary testing and counseling for HIV/AIDS and Family planning services were utilized by 47 (55.3\%) and 43 (50.6\%) of youths respectively. Being grade $11-12(\mathrm{AOR}=5.299,95 \% \mathrm{Cl} 2.019,13.912, \mathrm{P}=0.001)$ and closeness of the service facility to their home ( $A O R=2.76,95 \% \mathrm{Cl} 1.168,6.525, \mathrm{P}=0.021$ ) were significantly associated with students' reproductive health service utilization. This low service utilization might make students prone for different reproductive health risks; which in turn can increase school dropout rate, and has impact on individual's future life as well as the country's youth health policy from meeting its goal. Therefore, it needs a great effort and attention of all the concerned bodies including parents, school staffs, and health professionals to improve the service utilization in schools.
\end{abstract}

Keywords: Reproductive health service, Students, Utilization, Youth, Reproductive health, Ethiopia

\section{Introduction}

Reproductive health (RH) is a state of complete physical, mental and social well-being relating to the reproductive system; and not merely the absence of disease or infirmity [1]. According to World Health Organization (WHO), youths are described as a young person between the age group of 15 and 24 years [2]; those make up about $20 \%$ of the world's population [3]; of whom, $85 \%$ lives in developing countries [4]. Youths considered being the hope for future of one country and health condition of each individual as well as behavioral formation made during this period has also impact on development of the country $[1,5]$. Despite this, they have unique reproductive health risks of unplanned pregnancies and childbearing; sexually

\footnotetext{
*Correspondence: addisutaye60@gmail.com

1 Department of Medical Nursing, School of Nursing, College of Medicine and Health Sciences, University of Gondar, Gondar, Ethiopia

Full list of author information is available at the end of the article
}

transmitted infections (STIs) including Human Immuno Deficiency Virus (HIV) and unsafe abortion [6-9]. However, the access to and utilization of Reproductive Health services (RHS) is a primary concern for Youths surrounding the promotion of reproduction health and rights [10].

In Ethiopia, more than $1 / 3$ of the population is found between the age of 10-24, in which they are the most vulnerable to a range of reproductive health problems as a result of premarital sexual activities [11]. For Youths to effectively transit to adulthood, they need to be provided with factual, accessible and affordable reproductive health information and services $[3,12]$. As a response, the Ethiopian government, along with a number of international Non-Governmental Organizations (NGOs), has been supporting activities including the scale-up and institutionalization of Youth Friendly Services through intensive capacity building at all levels of the health system [13, 14]. However, the effects of all the efforts have not been felt across the Ethiopian learning institutions, 
as it is evidenced by persistent reproductive health problems and challenges of the youths such as unwanted pregnancy and its consequences: the rate of abortion among students was found to be 65 per 1000 women, making it threefold of the national rate of abortion for Ethiopia (23/1000 women aged 15-44); increasing prevalence of STIs including HIV/AIDS (19.5\%) [4, 15, 16]; unmet need for family planning and over a quarter of all Ethiopian pregnant youths and adolescents feel that their pregnancies are mistimed; high rates of delivery-related complications as well as a subsequent drop-out of school for many young girls $[17,18]$.

Secondary school students are the most vulnerable group for $\mathrm{RH}$ problems due to their inclination to be engaged in risky sexual behavior [16]. Additionally, the environment itself expose students to greater opportunities and circumstances for engaging in risky behaviors related to RH [19]. Furthermore, attracting youths to the clinical services has remained a challenge; however, there was a need to improve the health seeking behavior of these age groups [20]. Despite these, the response to deliver RHS for students has been fragmented and Ethiopian schools are limited in delivering health related services for their students. As a result significant proportion of their students are developing $\mathrm{RH}$ related problems [21]. Although such studies are important in resourcelimited areas, to give the present image of reproductive health service related issue of the students, there is no study conducted in Woreta town secondary school students regarding utilization of RHS; and the available literatures in Ethiopia were limited in addressing factors that influence utilization of RHS among secondary school students. Therefore, this study aimed to assess Utilization and factors affecting RHS among secondary School Students in Woreta town, North West Ethiopia.

\section{Main text}

\section{Study design, area and period}

Institutional based cross-sectional study was conducted from April 20 to May 15/2018 among secondary school students at Woreta town, North West Ethiopia.

\section{Sampling and participation}

The source population were all youths attending secondary school at Woreta town during 2018 academic year. All students who are 15-24 years old attending their secondary school within the town during the study period were included; whereas, those students who are seriously ill at time of data collection were excluded. The sample size was determined by using single population proportion formula by considering the following assumption: $32 \%$ proportion of RHS utilization [22], 95\% confidence interval, $5 \%$ margin of error and $5 \%$ for possible non-response.
Based on these, a total of 376 students was taken as a final sample size. In Woreta town, there was only one secondary school having a total of 3213 students attending grade 9-12 in 2018 and these are taken as a study population. The sample size was proportionally allocated to each grade and computer generated simple random sampling technique was used to select the study participants from each grade by using the list of all students in each grade as a sampling frame.

\section{Data collection tool and procedure}

Data collection was performed by Four B.Sc. nurses, who were properly trained for 2 days regarding the tool and the procedure (on the objective of the study, how to approach the students, how to administer and collect the questionnaires timely). The questionnaire was first prepared in English and then translated to local language, Amharic, and re-translated back to English to ensure consistency. The tool was tested on 18 secondary school students at Debretabore city and relevant modifications were done before the actual data collection period. Data on socio demographic characteristics, health care system factors/accessibility of RHS facility and reproductive health service utilization were collected by using structured self-administered questionnaire [23].

\section{Data processing and analysis}

After the questionnaires checked visually for completeness, entered into Epi Info version 7 and exported to Statistical Package for Social Sciences (SPSS) version 23 for analysis. Descriptive statistics including frequencies, percentages, summary statistics like mean and standard deviation were computed to describe the study participants. Binary logistic regression was employed to see the crude significant association of each variable to the outcome variable, RHS utilization. Then variables with $P$ value $<0.2$ in bi-variable logistic regression analysis were again entered into multivariable logistic regressions to see the independent effect of each explanatory variables with the outcome variable. Finally, variables having P-value $<0.05$ in multivariate analysis were considered as statistically significant predictor of RHS utilization based on adjusted odd ratio (AOR) with 95\% confidence level.

\section{Operational definition \\ Reproductive health service utilization}

Utilization of at least one of reproductive health services (HIV testing and counseling, STI screening and treatment, family planning counseling and contraceptive use, abortion service, and perinatal services) within the last 1 year [23]. Accessibility of RHS facility (geographical accessibility): in this study accessibility was measured 
in terms of estimated distance of RHS facility from their home [24].

\section{Results}

Socio-demographic characteristics of participants

A total of 345 students were participated in the study with a response rate of 94\%; out of this 184 (53\%) were females with a mean age of $17.8(\mathrm{SD} \pm 1.76)$ and almost half of them $179(51.8 \%)$ were grade 11 and 12. 277 $(80.3 \%)$ of student stated as they have discussed sex related issues with their parents in the past 1 year and
$236(68.4 \%)$ of them get pocket money for daily expenses (Table 1).

Utilization of $R H$ services by secondary school youths From the total of 345 school youths, 85 (24.6\%) of them utilized reproductive health services in the past 1 year. Regarding the components of RHS voluntary testing and counseling of HIV, family planning and condom were utilized by 47 (55.3\%), 43 (50.6\%) and 27 (31.8\%) youths respectively (Fig. 1).

Table 1 Socio-demographic characteristics of secondary school youths in Woreta town, South Gondar, Ethiopia 2018 $(n=345)$

\begin{tabular}{|c|c|c|c|}
\hline Variable & Category & Frequency & Percentage (\%) \\
\hline \multirow[t]{2}{*}{ Sex } & Male & 161 & 46.7 \\
\hline & Female & 184 & 53.3 \\
\hline \multirow[t]{2}{*}{ Age } & $15-19$ & 286 & 82.9 \\
\hline & $20-24$ & 59 & 17.1 \\
\hline \multirow[t]{2}{*}{ Grade level } & Grade 9-10 & 166 & 48.2 \\
\hline & Grade 11-12 & 179 & 51.8 \\
\hline \multirow[t]{3}{*}{ Religion } & Muslim & 23 & 6.7 \\
\hline & Protestant & 5 & 1.4 \\
\hline & Other & 1 & 0.3 \\
\hline \multirow[t]{4}{*}{ Ethnic group } & Amhara & 342 & 99.1 \\
\hline & Oromo & 2 & 0.6 \\
\hline & Tigre & 1 & 0.3 \\
\hline & Other & 0 & 0 \\
\hline \multirow[t]{6}{*}{ With whom do you usually live } & With my father and mother & 284 & 82.3 \\
\hline & With mother only & 29 & 8.4 \\
\hline & With father only & 7 & 2.0 \\
\hline & With relatives & 6 & 1.7 \\
\hline & With friends & 10 & 2.9 \\
\hline & Alones & 9 & 2.6 \\
\hline \multirow{3}{*}{$\begin{array}{l}\text { How often did you discuss sex related issues with your } \\
\text { parents }\end{array}$} & In the past 3 months & 30 & 8.7 \\
\hline & In the past 6 months & 38 & 11.0 \\
\hline & In the past 1 year and above & 277 & 80.3 \\
\hline \multirow[t]{5}{*}{ Parents education level } & Don't read and write & 72 & 20.9 \\
\hline & Reade and write only & 142 & 41.2 \\
\hline & Primary school & 46 & 13.3 \\
\hline & Secondary school & 30 & 8.7 \\
\hline & Diploma & 47 & 13.6 \\
\hline \multirow[t]{5}{*}{ Marital status of the mother and father } & Currently not live with parents & 8 & 2.3 \\
\hline & Together & 284 & 82.3 \\
\hline & Separate & 14 & 4.1 \\
\hline & Divorced & 15 & 4.3 \\
\hline & Widows & 32 & 9.3 \\
\hline \multirow[t]{2}{*}{ Do you get pocket money for daily expenses } & Yes & 236 & 68.4 \\
\hline & No & 109 & 31.6 \\
\hline
\end{tabular}




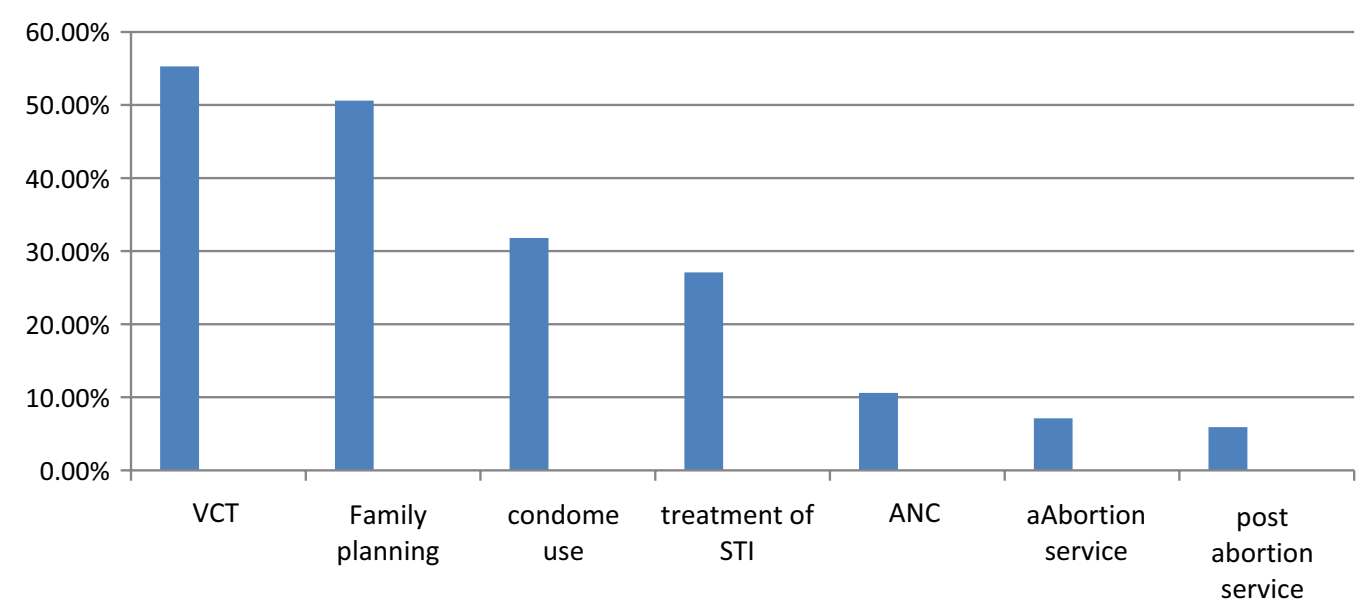

Fig. 1 Utilization of reproductive health service among secondary school students in Woreta town, South Gondar, Ethiopia, $2018(N=345)$

Factors associated with utilization of RHS On the bivariate analysis, sex, grade level of the youths, having pocket money for daily expense, parental educational status and nearness of RHS facility to the participants' home were identified to be significantly associated with youths' RHS utilization. During multivariable logistic analysis grade level of participants and closeness of RHS facility to their home were continued to be significant. The likely hood of RHS utilization was 5.299 times more likely in grade $11-12(\mathrm{AOR}=5.299,95 \%$ CI 2.019, 13.912, $\mathrm{P}=0.001)$ when compared to grade 9-10. Youths with RHS facility near to their home were 2.76 times more likely to utilize the service than far to their home $(\mathrm{AOR}=2.76,95 \% \mathrm{CI}$ $1.168,6.525, \mathrm{P}=0.021$ ) (Table 2).

\section{Discussion}

The overall utilization of RHS among secondary school youths in Woreta was found to be $24.6 \%$, (95\% CI $19.8 \%-29 \%$ ); which is in line with a study conducted in Nekemet [25], Madawalabu university [26], Mekele [27] and Mechakel, East Gojjam [28]; in which (21.2\%, 27.7\%, $23 \%$, and $21.5 \%$ ) of participants utilized RHS respectively. However, this finding is lower than studies conducted in Harare, Bahir Dar, Awabel and Hadiya Zone, Ethiopia, which showed that $(63.8 \%, 32 \%, 41.2 \%$ and $38.5 \%)$ of participants utilized at least one of the reproductive health service in the past 1 year [22, 29-31] respectively. The possible reason for this difference might be due to the participants' socio-demographic characteristics, time reference used in the definition of RHS utilization and socio economic variation. Furthermore, this discrepancy might be also due to differences in the availability and accessibility of reproductive health facilities and youth centers within the school.
In the current study, the commonly utilized RHS component was voluntary testing and counseling service $(55.3 \%)$ which is consistent with the findings of studies done in Harrar [29] and Mecha District, North West, Ethiopia [32]; in which $52.8 \%$ and $60.2 \%$ of participants utilized voluntary testing and counseling service respectively. But, differ from studies conducted in Hawassa, Madawalabu, Kenya and Nigeria, in which family planning was the commonly utilized RHS [26, 33-35] respectively. This discrepancy might be due to socio demographic variation like difference in age and maturation. For example, in Hawassa [33], and Madawalbu [26], the study was conducted among University students whose age and maturation are expected to be relatively higher than secondary school students. In addition, family and community influences are relatively low; but high peer influence and risk perception in university students than secondary school students. So, all these things might made difference in RHS utilization.

In this study, grade eleven and closeness of RHS facility to their home were found to be significantly associated with RHS utilization among school youths. In this regard, grade eleven and twelve students were Five times more likely to utilize RHS (AOR $=5.299,95 \%$ CI 2.019, 13.912, $\mathrm{P}=0.001$ ) compared to grade nine and ten students. This finding is supported by studies conducted in Addis Ababa, Ethiopia and Kenya where difference in educational level is significantly associated with RHS utilization [22, 34]. This might be due to the fact that becoming more disclosure for RHS information and secondary behavioral change as the grade level increases Similarly, Youths with RHS near to their home were 2.76 times more likely to utilize the service than Youths with RHS facility is far to their home (AOR $=2.76,95 \%$ CI 1.168 , 6.525, $\mathrm{P}=0.021$ ). 
Table 2 Factors associated with RH services utilization among secondary school students in Woreta town, South Gondar, Ethiopia 2018

\begin{tabular}{|c|c|c|c|c|c|c|}
\hline \multirow[t]{2}{*}{ Variables } & \multicolumn{2}{|c|}{ RH service utilization (\%) } & \multirow[t]{2}{*}{ COR $(95 \% \mathrm{Cl})$} & \multirow[t]{2}{*}{ P-value } & \multirow[t]{2}{*}{ AOR $(95 \% \mathrm{Cl})$} & \multirow[t]{2}{*}{$P$ value } \\
\hline & Yes & No & & & & \\
\hline \multicolumn{7}{|l|}{ Sex } \\
\hline Female & $51(60 \%)$ & $133(51.2)$ & $1.432(0.871,2.335)$ & 0.157 & $0.435(0.177,1.09)$ & 0.70 \\
\hline Male & $34(40 \%)$ & $127(48.8)$ & 1.00 & & 1.00 & \\
\hline \multicolumn{7}{|l|}{ Grade level } \\
\hline $11-12$ & $44(51.8 \%)$ & $41(48.2 \%)$ & 3.3.27 $(1.913,10.43)$ & 0.001 & 1.00 & \\
\hline $9-10$ & $41(48.2 \%)$ & $125(48.2 \%)$ & 1.00 & & $5.299(2.019,13.91)$ & $0.001^{*}$ \\
\hline \multicolumn{7}{|c|}{ Do you get pocket money for daily expense? } \\
\hline Get money for daily expense & $65(76.5 \%)$ & $171(65.8 \%$ & $0.591(0.337,1.038)$ & 0.067 & $2.595(0.153,0.856)$ & 0.50 \\
\hline Don't get money for daily expense & $20(23.5 \%)$ & $89(34.2 \%)$ & 1.00 & & 1.00 & \\
\hline \multicolumn{7}{|l|}{ Is RH service near to your home? } \\
\hline Near to home & $52(61.2 \%)$ & $130(50 \%)$ & $1.576(0.956,2.596)$ & 0.074 & $2.76(1.168,6.525)$ & $0.021^{*}$ \\
\hline Far to home & $33(38.8 \%)$ & $130(50 \%)$ & 1.00 & & 1.00 & \\
\hline \multicolumn{7}{|l|}{ Educational status of parent } \\
\hline Not read and write & $21(24.7 \%)$ & $51(19.6 \%)$ & 1.00 & & 1.00 & \\
\hline Read and write & 39 (45.9\%) & $103(39.6 \%)$ & $1.087(0.581,2.037)$ & 0.793 & $2.021(0.656,6.22)$ & 0.22 \\
\hline Primary education & 7 (8.2\%) & $39(15.0 \%)$ & $2.294(0.886,5.994)$ & 0.087 & $2.58(0.653,10.47)$ & 0.18 \\
\hline Secondary education & $9(10.6 \%)$ & $21(8.1 \%)$ & $0.961(0.378,2.439)$ & 0.933 & $1.434(0.284,8.41)$ & 0.69 \\
\hline Diploma and above & $8(9.45)$ & 39 (15.0\%) & $2.007(0.804,5.011)$ & 0.135 & $4.033(0.901,18.052)$ & 0.68 \\
\hline \multicolumn{7}{|l|}{ Convenient place for $\mathrm{RH}$ service } \\
\hline Anywhere out of the resident area & $51(60.0 \%$ & $140(53.8 \%)$ & $0.183(0.024,1.421)$ & 0.104 & $0.409(0.04,4.165)$ & 0.45 \\
\hline In the center of the town & $22(25.9 \%)$ & $67(25.8 \%)$ & $0.203(0.25,1.625)$ & 0.133 & $0.27(0.027,2.891)$ & 0.285 \\
\hline At the end of the town & $11(12.9 \%)$ & $38(14.6 \%)$ & $0.230(0.07,1.943)$ & 0.177 & $0.147(0.011,1.91)$ & 0.144 \\
\hline In the school & $1(1.2 \%)$ & $15(5.8 \%)$ & 1.00 & & 1.00 & \\
\hline
\end{tabular}

NB: variables having a $(\mathrm{P}<0.2)$ in bi variable (unadjusted) analysis included in the multivariable (adjusted) analysis

COR Crude odd ratio, $A O R$ adjusted odd ratio

* Statistically significant at $\mathrm{P}$-value $<0.05$

\section{Conclusion}

Reproductive health service utilization among secondary school students in Woreta town found to be low. This might make students prone for different problems related to reproductive health; which in turn can increase school dropout rate. The most frequently utilized RHS component was voluntary testing and counseling followed by family planning service. In this study grade 11-12 and closeness of facility near to their home were significantly associated with the service utilization. Overall, the finding requests the attention and effort of all concerned bodies including parents, school staffs, and health professionals to improve the service utilization in schools. Furthermore, a study supported by qualitative techniques should be done including youths' parents and service providers' opinion.

\section{Limitation}

Since the study was institutional based and which was also confined to the public school, generalization of the findings to the general youth population is limited. In addition, the study examines personal and sensitive issues through a quantitative study design with self-administered questionnaire, which may have subjectivity.

\section{Abbreviations}

AIDS: acquired immuno-deficiency syndrome; ANC: anti natal care; AOR: adjusted odd ratio; CL: confidence level; COR: Crude odds ratio; Epi info: statistical package for epidemiological information analysis; FP: family planning; HIV: human immuno-deficiency virus; OR: odds ratio; PNC: post natal care; RH: reproductive health; STI: sexual transmitted infection; STD: sexual transmitted disease; SPSS: Statistical Package for Social Science; University of Gondar: University of Gondar; VCT: Voluntary Counseling and Test; WHO: World Health Organization. 


\section{Authors' contributions}

AA wrote the proposal, participated in data collection and analysis and drafted the manuscript. TG/M and AT approved the proposal with revisions, participated in drafting, writing, reviewing, and approval of the manuscript for publication. All authors read and approved the final manuscript.

\section{Author details \\ ${ }^{1}$ Department of Medical Nursing, School of Nursing, College of Medicine and Health Sciences, University of Gondar, Gondar, Ethiopia. ${ }^{2}$ Department of Surgical Nursing, School of Nursing, College of Medicine and Health Sci- ences, University of Gondar, Gondar, Ethiopia.}

\section{Acknowledgements}

The authors thank Woreta secondary school staffs for their contribution during data collection and University of Gondar for giving ethical clearance. The authors would like to thank also the study participants for their valuable information.

\section{Competing interests}

The authors declare that they have no competing interests.

\section{Availability of data and materials}

To keep the participants' confidentiality, the raw data would not be shared. But, it is available from the corresponding author on reasonable request and the summary data are available in the main document.

\section{Consent for publication}

Not applicable.

\section{Ethics approval and consent to participate}

This study was approved by the Ethical committee of University of Gondar. After the purpose of the research has been explained to the study participants, a written informed consent was obtained from each students; additionally, consent was obtained from a parent on behalf of any participants under the age of 16. Confidentiality of the information and respondents were reassured that they were anonymous (unnamed). Participants were given a chance to ask anything about the study and their involvement in the study was on a voluntary basis; in addition, participants were made free to refuse or stop at any stage of the study.

\section{Funding}

No financial support was gained to conduct the study.

\section{Publisher's Note}

Springer Nature remains neutral with regard to jurisdictional claims in published maps and institutional affiliations.

Received: 18 December 2018 Accepted: 11 February 2019 Published online: 15 February 2019

\section{References}

1. Glasier A, Gülmezoglu AM, Schmid GP, Moreno CG, Look PFV. Sexual and reproductive health: a matter of life and death. Geneva: The Lancet Sexual and Reproductive Health Series; 2006.

2. Rosen J. Adolescent Health and Development. A Resource Guide for World Bank Operations Staff and Government Counterparts. Washington DC: International Bank for Reconstruction and Development/the World Bank; April. 2004.

3. WHO. Promoting Adolescent sexual and reproductive health through schools in low income countries; an information brief Department of child and adolescent health. Geneva: WHO; 2008.

4. elachew T, Nigussie S, Mengistie B. Manual on Reproductive Health. Ethiopia: Funded under USAID Cooperative Agreement No. 663-A-00-000358-00. 2003.

5. Belachew T, Jira Ch, Nigussie S, Alemyehu M, Mengistie B, Egata G, et al. Manual on reproductive health. Federal Democratic Republic of Ethiopia Ministry of Education and Ministry of Health; 2003.
6. Ingwersen R. Youth reproductive and sexual health in the developing world. Canberra: Development Studies Network; 2001.

7. Adefuye AS, Abiona TC, Balogun JA, Lukobo-Durrell M. HIV sexual risk behaviors and perception of risk among college students: implications for planning interventions. BMC Public Health. 2009;9:28.

8. Karl L D, Gabriele R. Sexually transmitted infections among adolescents the need for adequate health services: WHO and GTZ; 2005.

9. De BruynMaP. Adolescents' unwanted pregnancy and abortion. Policies, counseling and clinical care. USA: IPAS; 2004.

10. Braeken. D, Rondinelli. I. Sexual and reproductive health needs of young people: matching needs with systems, international federation of gynaecology and obstetrics, 2012.

11. Central Statistical Agency (CSA) [Ethiopia] and ICF International. Ethiopia Demographic and Health Survey 2011. Addis Ababa, Ethiopia and Calverton, Maryland, USA: CSA and ICF International, 2012.

12. Wood K, Aggleton P. Promoting young people's sexual and reproductive health: stigma, discrimination and human rights. London: Department for International Development (DfID).

13. Federal Democratic Republic of Ethiopia Ministry of Health, National Adolescent and Youth Reproductive Health Strategy (2007-2015) Addis Ababa.

14. The federal democratic republic of Ethiopia ministry of health. Health sector transformation plan (2015) 2015/16-2019/20 (2008-2012 EFY).

15. Gelaye AA. KNT, and TM, Magnitude and risk factors of abortion among regular female students in Wolaita Sodo University, Ethiopia. BMC Womens Health. 2014;14(50):1-9.

16. Govindasamy P, Kidanu A, Bantayerga $\mathrm{H}$. Youth reproductive health in Ethiopia. Calverton: ORC Macro; 2002.

17. FMOH. National reproductive health strategy 2006-2015; Federal democratic republic of Ethiopia, Ministry of health. 2006.

18. UNFPA. People and possibilities in a world of 7 billion, state of world population 2011: UNFPA; 2011.

19. Mehretie Y, Gebeyehu A, Birhanu Z. Knowledge of reproductive and sexual rights among University students in Ethiopia: institution-based cross-sectional. BMC Int Health Hum Rights. 2013;13:12.

20. Family Health International. Reproductive Health of Young Adults: Contraception, Pregnancy and Sexually Transmitted Diseases. Contraceptive Technology Update Series. Research Triangle Park, N.C.: Family Health International in collaboration with FOCUS on.

21. Association of African Universities: an HIV/AIDS Toolkit for Higher Education Institutions in Africa. Johannesburg, South Africa; 2004. http://www. aau.org.

22. Meskerem A, Worku A. Utilization of Youth Reproductive Health Services and Associated Factors among High School Students in Bahir Dar, Amhara Regional State, Ethiopia. Open J Epidemiol. 2014;4:69-75.

23. Kiran B, Fariha H, Rajendra K, Sophia Newman M, Asiful Haider C, Rajshree $\mathrm{T}$, Ismat B. Perceived sexual and reproductive health needs and service utilization among higher secondary school students in Urban Nepal. Am J Public Health Res. 2015;3(2):36-45. https://doi.org/10.12691/ajphr-3-2-1.

24. Biddlecom AE, Munthali A, Singh S, Woog V. Adolescents views of and preferences for sexual and reproductive health services in Burkina Faso, Ghana, Malawi and Uganda. Afr J Reprod Health. 2007;11(1):99-110.

25. Binu W, Marama T, Gerbaba M, Sinaga M. Sexual and reproductive health service utilization and associated factors among secondary school students in Nekemte town, Ethiopia. Reproductive Health. 2018;15:64.

26. Dida N, Darega B, Takele A. Reproductive health services utilization and its associated factors among Madawalabu University students, Southeast Ethiopia. BMC Res Notes. 2015;11:8.

27. Kalayu K, Berhe S, Alemayehu M. Utilization of youth friendly services and associated factors in Mekelle Town, Tigray, Northern Ethiopia. Int J Ther Appl. 2016;33:49-59.

28. Abajobir AA, Seme A. Reproductive health knowledge and services utilization among rural adolescents in east Gojjam zone, Ethiopia: a community-based cross-sectional study. BMC Health Serv Res. 2014;14:138.

29. Motum A, Syre T, Egata G, Kenay A. Utilization of youth friendly services and associated factors among youth in Harar town, east Ethiopia: a mixed method study. BMC Health Serv Res. 2016;16:272.

30. Ayehu A, Kassaw T, Hailu G. Level of young people sexual and reproductive health service utilization and its associated factors among young people in Awabel District, Northwest Ethiopia. PLOS ONE. 2016:11(3):e0151613. 
31. Helamo D, Kusheta S, Bancha B, Habtu Y, Yohannes S. Utilization and factors affecting adolescents and youth friendly reproductive health services among secondary school students in Hadiya Zone, Southern Nations, Nationalities and Peoples Region, Ethiopia. Int J Pub Heal Safe. 2017;2(141):2

32. Alehegn BG, Mulunesh TT, Yilkal TA, Abebaw AG. Sexual and reproductive health services utilization and associated factors among preparatory school students in Mecha District, Northwest Ethiopia: cross sectional study. J Gynecol Women's Health. 2018;11(5):555824. https://doi. org/10.19080/JGWH.2018.11.555824.
33. Tolossa E, Meshesha B, Alemu E. Assessment of level of knowledge and utilization of emergency contraception among female students of Hawassa University, South Ethiopia. Adv Reprod Sci. 2013;1:51-6.

34. Ontiri KK. Factors influencing utilization of reproductive health services amongst young people in rift valley provincial hospital, Nakuru CountyKenya. 2015.

35. Omobuwa O, Asekun-Olarinmoye EO, Olajide FO. Knowledge and perception of reproductive health services among in-school adolescents in Ilelfe, Osun State, Nigeria. J Med Med Sci. 2012;3:481-8.
Ready to submit your research? Choose BMC and benefit from:

- fast, convenient online submission

- thorough peer review by experienced researchers in your field

- rapid publication on acceptance

- support for research data, including large and complex data types

- gold Open Access which fosters wider collaboration and increased citations

- maximum visibility for your research: over 100M website views per year

At BMC, research is always in progress.

Learn more biomedcentral.com/submissions 